\title{
INTERFERENSI DALAM CERPEN SISWA SMP NEGERI 2 MERBAU MATARAM KABUPATEN LAMPUNG SELATAN
}

\author{
INTERFERENCE IN SHORT STORIES WRITTEN BY THE \\ STUDENTS OF SMPN 2 MERBAU MATARAM, \\ SOUTH LAMPUNG
}

\author{
Ratih Rahayu \\ Kantor Bahasa Provinsi Lampung \\ Jalan Beringin II No. 40 Kompleks Gubernuran Telukbetung, Bandarlampung \\ Telepon (0721) 486408, (0721) 480705, Faksimile (0721) 486407 \\ Pos-el: ahza.yayaya@gmail.com
}

\begin{abstract}
Abstrak
Penelitian ini berupaya melihat interferensi yang muncul dalam cerpen-cerpen yang ditulis oleh siswa-siswi SMP Negeri 2 Merbau Mataram, Lampung Selatan. Permasalahan yang diteliti adalah interferensi apa sajakah yang muncul dan faktorfaktor apakah yang menyebabkan terjadinya interferensi dalam cerpen-cerpen siswa tersebut. Pemakaian bahasa Indonesia dalam cerpen siswa-siswi SMP Negeri 2 Merbau Mataram ternyata diwarnai oleh interferensi dari bahasa asing (Inggris), bahasa gaul, dan bahasa daerah. Interferensi tersebut terjadi pada tataran morfologi, tataran leksikal, dan tataran sintaksis. Dari 40 cerpen yang diteliti ternyata ada 35 cerpen yang mengandung unsur interferensi. Hanya ada lima cerpen yang tidak diwarnai unsur interferensi. Apabila dipersentasekan secara keseluruhan ternyata cerpen siswa yang mengandung interferensi ada $87,5 \%$ dan yang tidak mengandung interferensi ada $12,5 \%$. Interferensi yang terjadi disebabkan oleh beberapa faktor, yaitu kedwibahasaan siswa, kebosanan, prestise, menghindari kekakuan, kosakata tersebut lebih singkat atau lebih pendek daripada padanannya dalam bahasa Indonesia, serta kosakata tersebut belum ada padanannya dalam bahasa Indonesia.
\end{abstract}

Kata kunci: interferensi, cerpen

\begin{abstract}
This research investigates the interference which exist in short stories written by the students of SMPN 2 Merbau Mataram, South Lampung Selatan. The problems investigated are the kinds of interference existing in the short stories and the factors which couse the interference in these short stories. The use of Indonesian in the short stories is the fact mixed with foreign languages (English), slang word, local languages. This interference occurs in morphological, lexical, and syntactical levels. From 40 short stories being investigated, there are 35 short stories in which the case of interference. There are only 5 short stories in which the case of interferences is not found. In these numbers are made into percentage, in total the percentage of short stories containing interference is $87,5 \%$ and the ones which are do not contain the interference is 12,5\%. The interference is caused by some factors, they are: the bilingualism of the student, boredom, prestige, avoiding unnatural phrases, the vocabularies are considered shorter compared to their equivalents in Indonesian, and the vocabularies do not have equivalents in Indonesia.
\end{abstract}




\section{Pendahuluan}

Bahasa nasional maupun bahasa daerah mana pun selalu akan mengalami perkembangan dan perubahan. Tentu saja hal ini terjadi karena adanya perubahan di dalam kehidupan manusia, baik sosial, ekonomi, maupun budaya. Adanya kontak di berbagai bidang ilmu pengetahuan, teknologi, sosial dan budaya dapat menyebabkan bahasa terpengaruh oleh bahasa lain. Proses saling memengaruhi antarbahasa ini tidak dapat dihindari, dan itulah yang dinamakan kontak bahasa.

Tidak dapat dimungkiri bahwa dalam masyarakat bilingual seperti di Indonesia seringkali digunakan dua bahasa atau lebih secara bergantian. Melalui proses inilah bahasa asing, bahasa daerah, dan bahasa gaul memengaruhi bahasa Indonesia. Hal ini sejalan dengan pendapat Sumarsono (2011:69) yang mengatakan bahwa adanya berbagai etnik dalam suatu negara dapat menimbulkan masalah kebahasaan, terutama dalam hal pengajaran.

Dalam dunia pendidikan di Indonesia, sejauh mana bahasa pertama siswa dapat mempengaruhi bahasa keduanya atau sebaliknya menyangkut masalah kefasihan menggunakan kedua bahasa tadi perlu diteliti. Sejauh mana pengaruh bahasa daerah, bahasa asing, dan bahasa gaul terhadap bahasa Indonesia dapat terlihat saat siswa menuangkannya dalam bentuk karangan. Oleh karena itu sejauh mana bahasa pertama seseorang dapat mempengaruhi bahasa keduanya atau sebaliknya perlu diteliti.

Beberapa dampak adanya penggunaan dua bahasa atau lebih dalam masyarakat adalah adanya alih kode, campur kode, interferensi dan integrasi. Alih kode merupakan peristiwa penggantian bahasa atau ragam bahasa oleh seorang penutur karena sebab-sebab tertentu dan dilakukan dengan sadar. Campur kode adalah digunakannya serpihan-serpihan dari bahasa lain dalam menggunakan suatu bahasa yang mungkin diperlukan sehingga tidak dianggap sebagai suatu kesalahan atau penyimpangan. Sedangkan interferensi adalah peristiwa digunakannya unsurunsur bahasa lain yang dianggap sebagai suatu kesalahan karena menyimpang dari kaidah atau aturan bahasa yang digunakan (Abdul Chaer, 2010:120).

Penelitian tentang interferensi dalam karangan siswa telah banyak dilakukan, misalnya yang telah dilakukan oleh Sugeng Nuryadi (2002), Prabingesti Anggarsika (2010), dan Lieza Yanti Fikrulloh (2011). Sugeng Nuryadi mencoba meneliti interferensi leksikal dialek Jakarta dalam karangan siswa kelas SD di Kelurahan Petir Kecamatan Cipondoh Tangerang. Penelitian Lieza Yanti Fikrulloh mencoba meneliti interferensi Bahasa Betawi pada Karangan Siswa Kelas XI SMK Miftahul Fallah, Cipulir Kebayoran Lama, Jakarta Selatan

Dari uraian di atas tampak bahwa penelitian terhadap gejala interferensi yang terjadi di dalam karangan siswa telah dilakukan oleh para peneliti. Namun, penelitian terhadap gejala interferensi yang terdapat dalam cerpencerpen yang ditulis oleh siswa dan siswi SMP di Provinsi Lampung belum dilakukan. Berdasarkan hal itulah, penulis tergugah untuk meneliti interferensi dalam cerpen-cerpen yang ditulis oleh siswa dan siswi SMP Negeri 2 Merbau Mataram, Kabupaten Lampung Selatan, Provinsi Lampung.

Penelitian ini bertujuan untuk mengetahui dan mendeskripsikan jenis- 
jenis interferensi yang terdapat dalam cerpen-cerpen yang ditulis oleh siswa dan siswi SMP Negeri 2 Merbau Mataram, Kabupaten Lampung Selatan, Provinsi Lampung. Selain itu, penelitian ini juga bertujuan untuk mengetahui faktor-faktor terjadinya interferensi tersebut. Penelitian ini merupakan penelitian dengan metode analisis deskriptif, yakni dengan menganalisis dan mendeskripsikan hasil temuan. Dalam kajian ini, akan diuraikan mengenai interferensi bahasa asing, bahasa daerah, dan bahasa gaul dalam cerpen-cerpen yang ditulis oleh siswa dan siswi kelas VIII SMP Negeri 2 Merbau Mataram, Lampung Selatan. Peneliti tidak hanya mengamati bagian yang memuat interferensi bahasa asing, bahasa daerah, dan bahasa gaul tersebut, tetapi juga mengamati konteks yang menyertai interferensi tersebut.

Data penelitian ini bersumber dari cerpen-cerpen yang ditulis oleh siswa dan siswi SMP Negeri 2 Merbau Mataram, Kabupaten Lampung Selatan, Provinsi Lampung. Data penelitian ini sesungguhnya adalah cerpen-cerpen yang ditulis oleh siswa dan siswi kelas VIII SMP Negeri 2 Merbau Mataram, Kabupaten Lampung Selatan, Provinsi Lampung. Sampel penelitian ini sebanyak 40 cerpen yang diambil dari kelas unggulan pada kelas VIII yang ada di SMP Negeri 2 Merbau Mataram, Kabupaten Lampung Selatan. Data yang diperoleh kemudian dianalisis menggunakan metode analisis deskripsi.

2. Cerpen, Interferensi Bahasa, dan Gambaran Umum SMPN 2 Merbau Mataram, Lampung Selatan

\subsection{Cerpen}

Cerpen merupakan kependekan dari cerita pendek. Cerpen merupakan salah satu contoh karya fiksi yangberupa karangan pendek berbentuk prosa. Menurut Edgar Allan Poe dalam Nurgiyantoro (2000:10), cerpen adalah sebuah cerita yang selesai dibaca dalam sekali duduk, kira-kira berkisar antara setengah sampai dua jam. Menurut Sumardjo dan Saini K.M. (1997: 37) cerpen adalah cerita fiktif atau tidak benar-benar terjadi, tetapi bisa saja terjadi kapanpun serta dimanapun yang mana ceritanya relatif pendek dan singkat.

Dalam Kamus Besar Bahasa Indonesia (KBBI) cerpen berasal dari dua kata yaitu cerita dan pendek yang mengandung arti tuturan mengenai bagaimana sesuatu hal terjadi dan relatif pendek berarti kisah yang diceritakan pendek atau tidak lebih dari 10.000 kata yang memberikan sebuah kesan dominan serta memusatkan hanya pada satu tokoh saja dalam cerita pendek tersebut.

Menurut Nugroho Notosusanto dalam Tarigan (1986:27), cerpen atau cerita pendek yaitu sebuah cerita yang panjang ceritanya berkisar 5000 kata atau perkiraan hanya 17 halaman kuarto spasi rangkap serta terpusat pada dirinya sendiri. Cerpen merupakan salah satu karangan fiksi yang biasa disebut juga dengan kisahan prosa pendek. J.S. Badudu berpendapat bahwa cerpen merupakan cerita yang hanya menjurus serta terfokus pada satu peristiwa saja. Sedangkan menurut pendapat $H$. B. Jassin, cerpen ialah sebuah cerita yang singkat yang harus memiliki bagian terpenting yakni perkenalan, pertikaian, serta penyelesaian.

Sebuah cerpen tidak melukiskan seluruh kehidupan pelakunya karena mengangkat masalah tunggal atau inti sarinya saja. Cerpen biasanya habis dibaca sekali duduk dan hanya mengisahkan sesuatu yang berarti bagi pelakunya saja. Tokoh-tokoh dalam cerpen seringkali dilukiskan mengalami konflik sampai pada penyelesaiannya. Pemilihan kata-kata dalam sebuah cerpen biasanya sangat ekonomis dan mudah dimengerti masyarakat. Cerpen sanggup meninggalkan kesan mendalam dan 
mampu meninggalkan efek pada perasaan pembaca.

Menurut Nurgiyantoro (2000: 11) ada beberapa kelebihan cerpen yang khas, yaitu kemampuannya mengemukakan lebih banyak dari sekadar apa yang diceritakan. Selain itu karena bentuknya yang pendek, cerpen menuntut penceritaan yang serba ringkas, tidak sampai pada detil-detil khusus yang kurang penting yang lebih bersifat memperpanjang cerita.

\subsection{Interferensi Bahasa}

Menurut Weinrich dalam Abdul Chaer (2010:120) istilah interferensi digunakan untuk menyebut adanya perubahan sistem suatu bahasa sehubungan dengan adanya persentuhan bahasa tersebut dengan unsur-unsur bahasa lain yang dilakukan oleh penutur yang bilingual. Namun, Hartman dan Stork dalam Abdul Chaer (2010:121) juga menyebut interferensi sebagai kekeliruan yang terjadi sebagai akibat terbawanya kebiasaan-kebiasaan ujaran bahasa ibu atau dialek kedua. Sedangkan Nababan (1993:33) mengatakan proses interferensi adalah pengacauan atau kekacauan.

Soewito (1983:59) mengemukakan bahwa interferensi dalam bahasa Indonesia dan bahasa-bahasa nusantara berlaku bolak-balik, artinya unsur bahasa daerah bisa memasuki bahasa Indonesia dan bahasa Indonesia banyak memasuki bahasa-bahasa daerah. Selanjutnya, menurutnya bahasa Indonesia hanya menjadi penerima dan tidak pernah menjadi pemberi.

Menurut Kunjana Rahardi (2001:164), interferensi muncul bukan karena si penutur mahir dalam menggunakan kode-kodenya dalam bertutur. Sebaliknya, interferensi muncul karena kurang dikuasainya kode-kode itu dalam bertutur. Dengan perkataan lain, interferensi itu dilakukan karena tidak mampunya kode yang dipakai dalam bertutur itu dikuasai oleh penutur.

Pengertian interferensi yang berkaitan dengan bilingualisme menurut Harimurti Kridalaksana (1993:84) adalah penggunaan unsur bahasa lain oleh bahasawan yang bilingual secara individual dalam suatu bahasa. Sedangkan interferensi yang berkaitan dengan pengajaran bahasa adalah kesalahan bahasa berupa unsur bahasa sendiri yang dibawa ke dalam bahasa atau dialek lain yang dipelajari. Dalam penelitian ini, tentu saja akan diteliti interferensi yang berkaitan dengan pengajaran bahasa karena respondennya siswa SMP.

Weinrich membagi interferensi berdasarkan bentuk. Berdasarkan bentuknya, interferensi terdiri atas interferensi bidang bunyi, interferensi bidang gramatika, dan interferensi bidang leksikal atau kosakata. Interferensi bidang gramatika terdiri atas interferensi morfologi dan sintaksis. Pendapat tersebut diperkuat oleh Samsuri (1983) dan Suwito (1983) mengemukakan bahwa interferensi mungkin terjadi pada tataran bunyi (fonologi), morfologi, sintaksis, dan semantik. Interferensi ini timbul akibat penggunaan atau pengetahuan beberapa buah bahasa (Rusyana: 1989).

Interferensi morfologi terjadi apabila dalam pembentukan kata suatu bahasa menyerap afiks bahasa lain. Interferensi sintaksis terjadi apabila stuktur kalimat suatu bahasa terserap struktur kalimat dari bahasa lain. Interferensi leksikal dapat berupa kata dasar, kata majemuk, dan frasa. Interferensi pada kata dasar merupakan pemindahan urutan fonemik sekaligus dari satu bahasa ke bahasa yang lain. Interferensi ini merupakan jenis interferensi yang paling umum.

Kunjana Rahardi (2001:164-165) menyatakan bahwa interferensi bukan karena si penutur mahir dalam 
menggunakan kode-kodenya dalam bertutur. Sebaliknya interferensi itu muncul karena kurang dikuasainya kodekode itu dalam bertutur. Dimungkinkan bahwa dalam alih kode seringkali di dalamnya terdapat interferensi. Hal demikian dimungkinkan karena orang yang beralih kode itu tidak semuanya menguasai bahasa yang dipakai dalam bertutur.

Faktor yang mendorong timbulnya interferensi dibedakan menjadi dua, yakni faktor bahasa dan faktor di luar struktur bahasa. Faktor struktur bahasa ialah faktor yang berasal dari susunan bahasa, yang merupakan sistem yang satu, yang berbeda pada setiap bahasa, sampai derajat tertentu, bebas dari pengenalan dan tingkah laku nonlinguistik. Weinrich mengemukakan bahwa makin besar perbedaan antara sistem-sistem itu, makin besar pula masalah belajar yang dihadapi dan kemungkinan terjadinya interferensi. Selain itu, tingkat keterikatan atau kebebasan unsur bahasa yang bersangkutan dapat pula mendorong terjadinya interferensi. Dari segi struktur bahasa, biasanya bahasa yang menggunakan morfem-morfem yang bebas dan tidak bervarian, yaitu pola yang lebih eksplisit, berlaku sebagai model untuk peniruan.

Faktor di luar struktur bahasa ialah faktor yang berasal dari kontak bahasa dunia luar, dari pengenalan individu dwibahasawan kepada bahasa itu, dan dari nilai simbolik yang diperoleh dari bahasa itu secara keseluruhan, serta dari emosi yang ditimbulkannya.

Interferensi dapat timbul karena beberapa faktor, faktor-faktor tersebut adalah kedwibahasaan para peserta tutur, tipisnya kesetiaan pemakai bahasa penerima, kurangnya kosakata bahasa penerima, hilangnya kosakata, kebutuhan sinonim, dan prestise bahasa sumber dan gaya bahasa.

\subsection{Gambaran Umum SMP Negeri 2 Merbau Mataram, Lampung Selatan}

SMP Negeri 2 Merbau Mataram berlokasi di Jalan Pejuang Angkatan 45 Kecamatan Merbau Mataram, Kabupaten Lampung Selatan, Provinsi Lampung.

Sekolah yang memiliki visi "berprestasi dan berakhlak mulia dengan dilandasi nilai-nilai budaya dan karakter bangsa" ini memiliki 1 orang kepala sekolah dan 32 guru yang terdiri dari 28 orang guru berstatus PNS dan 5 orang guru honorer. Selain itu, SMP Negeri 2 Merbau Mataram memiliki 9 orang staf tata usaha, 1 orang satpam, dan 1 orang penjaga sekolah.

Pada tahun ajaran 2013 - 2014 ini, SMP Negeri 2 Merbau Mataram memiliki 630 orang siswa yang terdiri dari 296 orang laki-laki dan 334 orang perempuan. Seluruh siswa tersebut terbagi dalam 16 kelas, yaitu 6 kelas VII, 5 kelas VIII, dan 5 kelas IX. Rata-rata tiap kelas terdiri dari 39 orang siswa.

\section{Hasil dan Pembahasan}

Pada bagian ini akan dipaparkan bentukbentuk interferensi yang ditemukan dalam cerpen-cerpen yang ditulis oleh siswa dan siswi SMP Negeri 2 Merbau Mataram, Kabupaten Lampung Selatan, Provinsi Lampung. Interferensi yang ditemukan dicari padanan katanya dalam bahasa Indonesia dan dimasukkan kembali dalam konteks kalimatnya.

\subsection{Sahabat yang Berbeda, Karya Aan Hargiawan}

Pada cerpen yang berjudul Sahabat yang Berbeda karya Aan Hargiawan ditemukan beberapa kalimat yang mengalami gejala interferensi pada tataran leksikal dan morfologi.

Unsur leksikal yang menginterferensi adalah banget, gitu, kalo, gini, sini, kale, hallo, ngapa, nggak papa, gak tauk, sama, telephon, 
ngerasain, bikin, kaya, dan nggak/gak. Unsur-unsur leksikal tersebut ada padanannya dalam bahasa Indonesia. Kata banget sepadan dengan kata sekali, kata gitu kependekan dari begitu, kata kalo sepadan dengan kalau, kata sini merupakan kependekan dari ke sini, kata kale sepadan dengan mungkin, kata hallo sepadan dengan hai, kata males sepadan dengan kata malas, kata ngapa sepadan dengan mengapa, kata nggak papa sepadan dengan tidak apa-apa, kata kaya sepadan dengan kata seperti, kata gak tauk sepadan dengan kata tidak tahu, kata sama sepadan dengan kata pada, kata telephon sepadandengan telepon, kata bikin seapadan dengan kata membuat, kata ngerasain sepadan dengan kata merasakan, dan kata gak sepadan dengan kata tidak.

Pemakaian unsur-unsur leksikal tersebut dilatarbelakangi oleh beberapa alasan. Pertama, unsur leksikal tersebut digunakan sebagai sinonim kata yang sudah ada dalam bahasa Indonesia. Kedua, bentuk sebagian unsur leksikal bahasa gaul itu lebih familiar daripada padanannya dalam bahasa Indonesia. Selain itu, kemungkinan alasan lainnya adalah kesengajaan penulis sebagai penguat latar sosial serta kebiasaan penulis cerpen yang terbiasa berbahasa gaul.

\subsection{Kelinci dan Kura-kura, Karya Agus Fajar Mahardeka}

Cerpen yang berjudul Kelinci dan Kurakura karya Agus Fajar Mahardeka memiliki tiga kalimat yang mengalami gejala interferensi pada tataran leksikal. Unsur leksikal yang ditemukan adalah emang, startnya, dan finish. Kata emang, startnya, dan finish terpengaruh bahasa gaul dan bahasa Inggris. Unsur leksikal pada kata tersebut ada padanannya dalam bahasa Indonesia. Kata emang berpadan dengan kata memang, kata startnya berpadan dengan kata awal (garis awal), dankata finishberpadanan dengan garis akhir.

Unsur leksikal yang digunakan dalam kalimat tersebut dilatarbelakangi oleh beberapa alasan. Pertama, unsur leksikal tersebut digunakan sebagai sinonim kata yang sudah ada dalam bahasa Indonesia. Kedua, bentuk sebagian unsur leksikal bahasa gaul dan bahasa Inggris itu lebih singkat daripada padanannya dalam bahasa Indonesia. Selain itu, kemungkinan alasan lainnya adalah kesengajaan penulis untuk menghindari kekakuan dialog tokohnya.

\subsection{Bunga Terakhir untuk Albina, Karya Alda Anisya Putri}

Dalam cerpen yang berjudulBunga Terakhir untuk Albina karya Alda Anisya Putri didapatkan beberapa kalimat yang mengalami gejala interferensi pada tataran leksikal dan sintaksis. Unsur leksikal yang ditemukan terpengaruh bahasa gaul dan bahasa Inggris. Unsur leksikal yang ditemukan adalah kata gimana,udah bosen, kaya gini, udahudah, udah, gak ada, udah deh, banget, makasih, you are is the best,aja, sebenernya, udah capek, thanks supportnya, mensuport, best friend forever.

Kata gimana sepadan dengan kata bagaimana, kata udah bosen sepadan dengan kata sudah bosan, kata kaya gini sepadan dengan kata seperti ini, kata udah-udah sepadan dengan kata sudahsudah, kata udah sepadan dengan kata sudah, kata gak ada sepadan dengan tidak ada, kata udah deh sepadan dengan sudahlah, kata banget sepadan dengan sangat, kata makasih sepadan dengan terima kasih, frasa you are is the bestsepadan dengan kamulah yang terbaik, kata sebenernya sepadan dengan sebenarnya, kata udah capek sepadan dengan sudah lelah, frasa thanks supportnya sepadan dengan terimakasih atas motivasinya, kata mensuport 
sepadan dengan kata mendukung, frasa best friend forever sepadan dengan sahabat selamanya.

Penggunaan unsur leksikal tersebut tampaknya dilatarbelakangi oleh beberapa alasan. Pertama, unsur leksikal tersebut digunakan sebagai sinonim kata yang sudah ada dalam bahasa Indonesia. Kedua, bentuk sebagian unsur leksikal bahasa gaul dan bahasa Inggris itu lebih familiar dan singkat daripada padanannya dalam bahasa Indonesia. Selain itu, kemungkinan alasan lainnya adalah kesengajaan penulis untuk menghindari kekakuan dialog tokohnya.

\subsection{Melawan Kanker Ganas, Karya Alfi Khoirun Nisa}

Dalam cerpen yang berjudul Melawan Kanker Ganas karya Alfi Khoirun Nisa terdapat dua kalimat yang memiliki gejala interferensi pada tataran leksikal. Unsur leksikal yang ditemukan adalah pada kata gak dandance. Kata dance terpengaruh bahasa Inggris. Kata gak terpengaruh bahasa gaul. Unsur leksikal kata dance berpadanan dengan kata tari dan kata gak berpadanan dengan tidak.

Penggunaan unsur leksikal tersebut dilatarbelakangi oleh beberapa alasan. Pertama, unsur leksikal tersebut digunakan sebagai sinonim kata yang sudah ada dalam bahasa Indonesia. Kedua, bentuk sebagian unsur leksikal bahasa gaul dan bahasa Inggris itu lebih familiar daripada padanannya dalam bahasa Indonesia. Selain itu, kemungkinan alasan lainnya adalah kesengajaan penulis untuk menghindari kekakuan dialog tokohnya.

\subsection{Dendam Andiko, Karya Ana Riani}

Pada cerpen Dendam Andiko karya Ana Riani terdapat beberapa kalimat yang mengandung interferensi. Unsur leksikal dan morfologi yang ditemukan adalah pada kata sana, sama, nyuruh, aja, loe,gue, babu elo, gak usah nyolot geh, cewek, kayabegituan, gak salah, ngaku aja. Kata-kata tersebutterpengaruh bahasa gaul. Unsur leksikal kata sana sepadan dengan kata ke sana, kata sama sepadan dengan kata pada, kata nyuruh sepadan dengan kata menugasi, kata aja sepadan dengan kata saja, kata loe sepadan dengan kata kamu, kata gue sepadan dengan kata saya/aku, kata babu elo sepadan dengan kata pembantumu, kata gak usah nyolot sepadan dengan kata tidak perlu membentak, kata cewek sepadan dengan kata perempuan, kata kayabegituan sepadan dengan kata seperti itu, kata gak salah sepadan dengan kata tidak salah, kata ngaku aja sepadan dengan mengaku saja.

Penggunaan unsur leksikal tersebut dilatarbelakangi oleh beberapa alasan. Pertama, unsur leksikal tersebut digunakan sebagai sinonim kata yang sudah ada dalam bahasa Indonesia. Kedua, bentuk sebagian unsur leksikal bahasa gaul itu lebih familiar daripada padanannya dalam bahasa Indonesia. Selain itu, kemungkinan alasan lainnya adalah kesengajaan penulis untuk menghindari kekakuan dialog tokohnya.

\subsection{Rumah Nenek Sihir Jahat, Karya Andiko H}

Pada cerpen yang berjudul Rumah Nenek Sihir Jahat karya Andiko H. tidak ditemukan kalimat yang mengalami gejala interferensi pada tataran leksikal maupun morfologi.

\subsection{Taman Kenangan Persahabatan, Karya Ani Yulianita}

Pada cerpen yang berjudul Taman

Kenangan Persahabatan karya Ani Yulianita ditemukan satu kalimat yang mengalami gejala interferensi pada tataran leksikal. Unsur leksikal yang ditemukan adalah pada kata enggak tau. Kata tersebutterpengaruh bahasa gaul. 
Unsur leksikal kata enggak tau berpadanan dengan kata tidak tahu.

Penggunaan unsur leksikal tersebut dilatarbelakangi oleh beberapa alasan. Pertama, unsur leksikal tersebut digunakan sebagai sinonim kata yang sudah ada dalam bahasa Indonesia. Kedua, bentuk sebagian unsur leksikal bahasa gaul itu lebih familiar daripada padanannya dalam bahasa Indonesia. Selain itu, kemungkinan alasan lainnya adalah kesengajaan penulis untuk menghindari kekakuan dialog tokohnya.

\subsection{Mengapa Aku Berbeda, Karya Avina Dea Eriska}

Pada cerpen yang berjudul Mengapa Aku Berbeda karya Avina Dea Eriska tidak ditemukan kalimat yang mengalami gejala interferensi pada tataran leksikal maupun morfologi.

\subsection{Bebek dan Soang, Karya Desi Mariyana}

Cerpen yang berjudul Bebek dan Soang karya Desi Mariyana tidak mengalami gejala interferensi baik pada tataran leksikal maupun pada tataran sintaksis.

\subsection{Salah Paham, Karya Dinda Dewi Nurlatifah}

Pada cerpen yang berjudul Salah Pahamkarya Dinda Dewi Nurlatifah terdapat dua kalimat yang mengalami gejala interferensi pada tataran leksikal. Unsur-unsur leksikal yang ditemukan adalah udah, nggak usah ngeles deh. Unsur leksikal tersebut berasal dari bahasa gaul dan ada padanannya dalam bahasa Indonesia. Kata udahberpadan dengan sudah, kata nggak usah ngeles dehberpadan dengan tidak perlu mengingkarinya.

Penggunaan unsur leksikal tersebut tampaknya dilatarbelakangi oleh beberapa alasan. Pertama, unsur leksikal tersebut digunakan sebagai sinonim kata yang sudah ada dalam bahasa Indonesia.
Kedua, bentuk sebagian unsur leksikal bahasa gaul itu terasa lebih khas daripada padanannya dalam bahasa Indonesia. Selain itu, kemungkinan alasan lainnya adalah kesengajaan penulis untuk menghindari kekakuan dialog tokohnya.

\subsection{Anugerah Tuhan yang Maha Esa, Karya Dwiki Ihwan M.}

Dalam cerpen yang berjudulAnugerah Tuhan yang Maha Esakarya Dwiki Ihwan M. terdapat dua kalimat yang mengalami gejala interferensi pada tataran leksikal.Unsur leksikal yang ditemukan adalah denger-denger dan ditarok mana. Unsur leksikal tersebut berasal dari bahasa gaul dan ada padanannya dalam bahasa Indonesia. Kata denger-denger berpadan dengan yang kudengar dan ditarok mana berpadan dengan kata diletakkan di mana.

Penggunaan unsur leksikal tersebut tampaknya dilatarbelakangi oleh beberapa alasan. Pertama, unsur leksikal tersebut digunakan sebagai sinonim kata yang sudah ada dalam bahasa Indonesia. Kedua, bentuk sebagian unsur leksikal bahasa gaul itu adalah kesengajaan penulis untuk memberi kesan berbeda atau khas dialog tokohnya.

\subsection{Bermain Curang, Karya Ernita Amelia}

Pada cerpen yang berjudul Bermain Curangkarya Ernita Amelia tidak terdapat kalimat yang mengalami gejala interferensi pada tataran leksikal maupun morfologi.

\subsection{Memancing di Pinggir Danau Berhantu, Karya Fajar Dwi Gusti} Dalam cerpen yang berjudul Memancing di Pinggir Danau Berhantu karya Fajar Dwi Gusti terdapat beberapa kalimat yang mengalami gejala interferensi pada tataran leksikal. Unsur leksikal yang ditemukan adalah ninggalin, kelamaan, 
mending, yuk mending, aja, mending beli, ya udah,nggak mau, mending gua, bareng sama, dan kecapean. Unsur leksikal tersebut ada padanannya dalam bahasa Indonesia. Kata ninggalin sepadan dengan kata meninggalkan, kata kelamaan sepadan dengan kata terlalu lama, kata mending sepadan dengan kata lebih baik, kata yuk mending sepadan dengan kata ayo lebih baik, kata aja sepadan dengan kata saja, kata mending beli sepadan dengan kata lebih baik beli, kata ya udah sepadan dengan kata ya sudah, kata nggak mau sepadan dengan kata tidak mau, kata mending gua sepadan dengan lebih baik saya/aku, kata bareng sama sepadan dengan kata bersama-sama, dan kata kecapean sepadan dengan kata kelelahan.

Penggunaan unsur leksikal tersebut tampaknya dilatarbelakangi oleh beberapa alasan. Pertama, unsur leksikal tersebut digunakan sebagai sinonim kata yang sudah ada dalam bahasa Indonesia. Kedua, kesengajaan penulis untuk memberi suasana yang berbeda dalam dialog tokohnya.

\subsection{Sahabat Selamanya, Karya Faris Dinda Fasha}

Pada cerpen yang berjudul Sahabat Selamanya karyaFaris Dinda Fasha terdapat tiga kalimat yang mengalami gejala interferensi pada tataran leksikal. Unsur leksikal yang ditemukan adalah lagi mau nembak cewek, lagi, begini, dan mending. Unsur leksikal tersebut berasal dari bahas gaul yang ada padanannya dalam bahasa Indonesia. Frasa lagi mau nembak sepadan dengan frasa sedang mau menyatakan cinta, kata cewek sepadan dengan kata perempuan, kata lagi sepadan dengan kata sedang, katabegini sepadan dengan kata seperti ini, dan kata mending sepadan dengan kata lebih baik.

Penggunaan unsur leksikal tersebut tampaknya dilatarbelakangi oleh beberapa alasan. Pertama, unsur leksikal tersebut digunakan sebagai sinonim kata yang sudah ada dalam bahasa Indonesia. Kedua, kesengajaan penulis untuk memberi suasana yang berbeda yang menambah kesan akrab dalam dialog tokohnya.

\subsection{Tukang Sepatu dan Liliput, Karya Ferawati}

Dalam cerpen yang berjudul Tukang Sepatu dan Liliput karya Ferawati tidak terdapat kalimat yang mengalami gejala interferensi pada tataran leksikal maupun sintaksis.

\subsection{Pencuri Jambu Disengat Lebah, Karya Handi Ferdiansyah}

Dalam cerpen yang berjudul Pencuri Jambu Disengat Lebah karya Handi Ferdiansyah terdapat beberapa kalimat yang mengalami gejala interferensi pada tataran leksikal. Unsur leksikal yang ditemukan adalah gak tau sih, nyolong, nggak deh, apaan nich,kapok, enggak mau,loe gak salah, enggak, dan udah selamet. Unsur leksikal tersebut berasal dari bahasa gaul yang telah ada padanannya dalam bahasa Indonesia. Kata gak tau sih sepadan dengan kata tidak tahu, kata nyolong sepadan dengan kata mencuri, kata nggak deh sepadan dengan kata tidaklah, kata apaan nich sepadan dengan kata ada apa ini, kata kapok sepadan dengan kata jera, kata enggak mau sepadan dengan kata tidak mau, kata loe gak salah sepadan dengan kata kamu tidak bersalah, kata enggak sepadan dengan kata tidak, dan kata udah selamet sepadan dengan kata sudah selamat.

Penggunaan unsur interferensi leksikal pada kalimat di atas, sepertinya muncul karena beberapa alasan berikut. Pertama, unsur leksikal tersebut digunakan sebagai sinonim kata yang sudah ada dalam bahasa Indonesia. Kedua, kesengajaan penulis untuk 
memberi suasana yang berbeda yang menambah kesan akrab dalam dialog tokohnya.

\subsection{Sahabat Saling Membantu, Karya Hesti Aprilia Anggraini}

Pada cerpen yang berjudul Sahabat Saling Membantu karya Hesti Aprilia Anggraini terdapat beberapa kalimat yang mengalami gejala interferensi pada tataran leksikal. Interferensi yang ditemukan sebagian besar berasal dari bahasa gaul. Interferensi ada dalam bentuk dasar, berimbuhan, dan bentuk ulang.

Interferensi leksikal bentuk dasar dalam cerpen ini yaitu tau nggak, abis ulangan tau, sampe segitunya, apaan, mautaunggak, susah tau, enggak bisa, gimana, enggak tau, kamu orang sih enak, ngomong, kan gak sepinter, udahlah, mah enggak asyik, lagi ngapain, enggak lagi ngapa-ngapain kok, udah di sini, kita cariin, ngasih tau, udah denger, dan kalok gitu. Kata tau nggak sepadan dengan kata tahu tidak, frasa abis ulangan tau sepadan dengan frasa habis ulangan tahu, kata sampe sepadan dengan kata sampai, kata segitunya sepadan dengan kata begitu, kata apaan sepadan dengan kata apa, frasa mautaunggak sepadan dengan frasa mau tahu tidak, kata susah tau sepadan dengan kata susah tahu, kata enggak bisa sepadan dengan kata tidak bisa, kata gimana sepadan dengan kata bagaimana, kata enggak tau sepadan dengan kata tidak tahu, frasa kamu orang sih enak sepadan dengan frasa kamu sih enak, kata ngomong sepadan dengan kata bicara, kata gak sepinter sepadan dengan kata tidak sepintar, kata udahlah sepadan dengan kata sudahlah, frasa mah enggak asyik sepadan dengan frasa tidak asyik, kata lagi sepadan dengan kata sedang, kata ngapain sepadan dengan kata sedang apa, frasa enggak lagi ngapangapain kok sepadan dengan frasa tidak sedang apa-apa kok, kata udah sepadan dengan kata sudah, kata cariin sepadan dengan kata carikan, kata ngasih tau sepadan dengan kata memberitahu, kata denger sepadan dengan kata dengar, dan kata kalok gitu sepadan dengankata kalau begitu.

\subsection{Awal dari Sebuah Persahabatan, Karya Hidayati Suparman}

Pada cerpen yang berjudul Awal dari Sebuah Persahabatan karya Hidayati Suparman terdapat beberapa kalimat yang mengalami gejala interferensi pada tataran leksikal. Interferensi yang ditemukan sebagian besar berasal dari bahasa gaul.

Interferensi leksikal dalam cerpen ini yaitu gak boleh gitu, lo, udah-udah, biarin aja, gak papa kok, ayok, tu tuh, deket kok, dah dateng,duluan, gak usah ngesok deh, ga ngerti,ga usah sok ga tau lo, kasian deh lo, loe masih mau bantuin gue, guecuma gamau cari gara-garaaja, lagian kan, lo tuh emang baek banget, maafin gue, udah baikan, dan OK. Frasa gak boleh gitu sepadan dengan frasa tidak boleh begitu, kata lo sepadan dengan kata kamu, kata udah-udah sepadan dengan kata sudah-sudah, kata biarin sepadan dengan kata biarkan, kata aja sepadan dengan kata saja, frasa gak papa kok sepadan dengan frasa tidak apa-apa kok, kata ayok sepadan dengan kata ayo, kata tu tuh sepadan dengan kata itu tuh, kata deket sepadan dengan kata dekat, kata dah dateng sepadan dengan kata sudah datang, kata duluan sepadan dengan kata lebih dulu, frasa gak usah ngesok deh sepadan dengan tidak usah sombong deh, kata ga ngerti sepadan dengan kata tidak mengerti, frasa ga usah sok ga tau lo sepadan dengan frasa tidak usah purapura tidak tahu kamu, frasa kasian deh lo sepadan dengan frasa kasihan deh kamu, kata loe sepadan dengan kata kamu, kata bantuin sepadan dengan kata membantu, kata gue sepadan dengan kata $a k u$, kata 
Cuma sepadan dengan kata hanya, frasa gamau cari gara-garaaja sepadan dengan frasa tidak mau mencari masalah, kata lagian sepadan dengan kata lagipula, kata emang sepadan dengan kata memang, kata baek sepadan dengan kata baik, kata banget sepadan dengan kata sekali, kata maafin sepadan dengan kata maafkan, kata gue sepadan dengan kata aku/saya, kata udah sepadan dengan kata sudah, kata baikan sepadan dengan kata lebih baik, dan kata $O K$ sepadan dengan kata baiklah.

Interferensi leksikal yang ditemukan, sepertinya muncul karena beberapa alasan berikut. Pertama, unsur leksikal tersebut digunakan sebagai sinonim kata yang sudah ada dalam bahasa Indonesia. Kedua, kesengajaan penulis untuk memberi suasana yang berbeda yang menambah kesan akrab dalam dialog tokohnya.

\subsection{Diary TerakhirAlika, Karya Ika Diana Zuhri}

Pada cerpen yang berjudul Diary Terakhir Alika karya Ika Diana Zuhri terdapat beberapa kalimat yang mengalami gejala interferensi pada tataran leksikal. Interferensi yang terdapat dalam cerpen ini berasal dari bahasa bahasa gaul dan bahasa Inggris. Interferensi ada dalam bentuk dasar, bentuk ulang dan frasa atau kelompok kata.

Interferensi leksikal yang ditemukan yakni "Happy birthday Lika", "Happy birthday to you", Cuma, aja, duluan, Dear diary, udah, jagain, enggak enak nih, ngomong gitu, kali aja, mending, samperin, kali aja,kaya enggak ada, gimana, enggak mau,ngerti”, nemenin kok, dan bakal kangen.

Padanan ataupun makna dari katakata tersebut adalah sebagai berikut. "Happy birthday Lika" sepadan dengan selamat ulang tahun lika, "Happy birthday to you" sepadan dengan selamat ulang tahun untukmu, kata cuma sepadan dengan hanya, kata aja sepadan dengan saja, kata duluan sepadan dengan kata lebih dulu, kata udah sepadan dengan kata sudah, kata jagain sepadan dengan kata menjaga, kata enggak enak nih sepadan dengan tidak enak nih, kata ngomong gitu sepadan dengan bicara begitu, kata kali aja sepadan dengan mungkin saja, kata mending sepadan dengan lebih baik, kata samperin sepadan dengan datangi, kat kali aja sepadan dengan mungkin saja, kata kaya enggak ada sepadan dengan seperti tidak ada, kata gimana sepadan dengan bagaimana, kata enggak mau sepadan dengan tidak mau, kata ngerti sepadan dengan kata paham, kata nemenin kok sepadan dengan kata menemani, kata bakal kangen sepadan dengan akan rindu, dan dear diarydalam bahasa Indonesia berpadanan dengan kata buku harianku.

Interferensi dalam cerpen ini seluruhnya berasal dari bahasa Inggris dan bahasa gaul. Kata-kata tersebut merupakan kata-kata yang sering digunakan oleh kalangan anak muda atau yang berjiwa muda. Hal ini didukung oleh latar belakang usia pengarangnya yang masih muda yaitu sekitar awal belasan tahun. Penggunaan unsur interferensi leksikal pada kalimat di atas, sepertinya muncul karena beberapa alasan berikut. Pertama, unsur leksikal tersebut digunakan sebagai sinonim kata yang sudah ada dalam bahasa Indonesia. Kedua, kesengajaan penulis untuk memberi suasana yang berbeda yang menambah kesan akrab dalam dialog tokohnya.

\subsection{Ujian Sekolah, Karya Ika Lusiani} Pada cerpen yang berjudul Ujian Sekolah karya Ika Lusiani terdapat beberapa kalimat yang mengalami gejala interferensi pada tataran leksikal. Interferensi yang ditemukan berasal dari bahasa gaul. Interferensi bahasa gaul 
dalam kalimat-kalimat di atas yaitu gua, apaan, ngomongin, cowok, dan apaan. Padanan ataupun makna dari kata gua adalaha aku atau saya, kata apaan sepadan dengan kata apa, katangomongin sepadan dengan membicarakan, dan kata cowok sepadan dengan kata laki-laki.

Penggunaan unsur interferensi leksikal pada kalimat di atas, sepertinya muncul karena beberapa alasan berikut. Pertama, unsur leksikal tersebut digunakan sebagai sinonim kata yang sudah ada dalam bahasa Indonesia. Kedua, kesengajaan penulis untuk memberi suasana yang berbeda yang menambah kesan akrab dalam dialog tokohnya.

\subsection{Cara Perkenalan yang Gagal, Karya Kelvin Ardy}

Dalam cerpen yang berjudul Cara Perkenalan yang Gagal karya Kelvin Ardy terdapat beberapa kalimat yang mengalami gejala interferensi pada tataran leksikal. Interferensi yang ditemukan berasal dari bahasa gaul yang muncul dalam bentuk dasar dan kelompok kata atau frasa.

Interferensi leksikal dalam bentuk dasar yang ditemukan yaitu guys, lagi, lagi ngomongin, emangnya, elo gak, guaaja, ketemu ya sama, elo siap gak, gak, gua, dah gak, diem aja, gak mau ganggu elo, ditungguin, sama, guagak, bantuin gua, nembakdya, elo bisa gak, mah gampang, dan gua ajarin. Kata-kata tersebut ada padanan katanya dalam bahasa Indonesia. Kata guys sepadan dengan kata teman-teman, kata lagi sepadan dengan kata sedang, frasa lagi ngomongin sepadan dengan sedang membicarakan, kata emangnya sepadan dengan memangnya, kata elo gak sepadan dengan kamu tidak, kata guaaja sepadan dengan kata aku saja, kata ketemu sepadan dengan kata bertemu, kata sama sepadan dengan kata dengan, kata gak sepadan dengan tidak, kata gua sepadan dengan aku, kata diem aja sepadan dengan kata diam saja, frasa gak mau ganggu elo sepadan dengan tidak mau mengganggumu, kata ditungguin sepadan dengan kata ditunggui, kata sama sepadan dengan, kata guagak sepadan dengan aku tidak, kata bantuin gua sepadan dengan bantu aku, kata nembakdya sepadan dengan menyatakan cinta padanya, kata elo bisa gak sepadan dengan kamu bisa tidak, kata gampang sepadan dengan mudah, dan kata gua ajarin sepadan dengan aku ajari.

Penggunaan unsur interferensi leksikal tersebut sepertinya muncul karena beberapa alasan berikut. Pertama, unsur leksikal tersebut digunakan sebagai sinonim kata yang sudah ada dalam bahasa Indonesia. Kedua, kesengajaan penulis untuk memberi suasana yang berbeda yang menambah kesan akrab dalam dialog tokohnya.

\subsection{Jauhi Aku, Karya Lidya Aldi Melyani}

Dalam cerpen yang berjudul Jauhi Aku karya Lidya Aldi Melyaniterdapat beberapa kalimat yang mengalami gejala interferensi pada tataran leksikal. Interferensiyang ada dalam cerpen ini berasal dari bahasa gaul. Interferensi leksikal dari bahasa gaul tersebut adalah gak, kayaknya, buruan, bentar, udah, yok, dan yaudah ayok.

Kata-kata tersebut mempunyai padanannya dalam bahasa Indonesia. Kata gak sepadan dengan kata tidak, kata kayaknya sepadan dengan kata sepertinya, kata buruan sepadan dengan kaya segera, kata bentar sepadan dengan kata sebentar, kata udah sepadan dengan kata sudah, kata yok sepadan dengan kata ayo, dan frasa yaudah ayok sepadan dengan kata ya sudah ayo.

Penggunaan unsur interferensi leksikal yang ditemukan, sepertinya muncul karena beberapa alasan berikut. Pertama, unsur leksikal tersebut 
digunakan sebagai sinonim kata yang sudah ada dalam bahasa Indonesia. Kedua, kesengajaan penulis untuk memberi suasana yang berbeda yang menambah kesan akrab dalam dialog tokohnya.

\subsection{Sahabat Setia, Karya M Maulana Yusuf}

Pada cerpen yang berjudul Sahabat Setia karya M. Maulana Yusuf terdapat kalimat yang mengalami gejala interferensi pada tataran leksikal. Unsur leksikal yang ditemukan adalah tau gak, balikan, ngejar-ngejar,ngapa, tuh, aja, loe,kalo, ngomong, gue, enggak, udah-udah, dan jadian. Unsur-unsur leksikal tersebut ada padanannya dalam bahasa Indonesia. Kata tau gak sepadan dengan tahu tidak, kata balikan sepadan dengan kembali (berpacaran), kata ngejar-ngejar sepadan dengan mengejar-ngejar, kata ngapa sepadan dengan mengapa, kata tuh sepadan dengan itu, kata aja sepadan dengan kata saja, kata loe sepadan dengankata kamu, kata kalo sepadan dengan kata kalau, kata ngomong sepadan dengan kata berbicara, kata gue sepadan dengan kata saya, kata enggak sepadan dengan tidak, kata udah-udah sepadan dengan kata sudah-sudah, kata jadian sepadan dengan frasa resmi berpacaran.

Penggunaan unsur-unsur leksikal tersebut tampaknya dilatarbelakangi oleh beberapa alasan. Pertama, unsur leksikal tersebut digunakan sebagai sinonim kata yang sudah ada dalam bahasa Indonesia. Kedua, unsur leksikal tersebut sengaja digunakan agar tidak terjadi kekkuan dialog tokoh-tokohnya.

\subsection{Sahabat Selamanya, Karya Mayang Andriyani}

Dalam cerpen yang berjudulSahabat Selamanya karya Mayang Andriyani terdapat beberapa kalimat yang mengalami gejala interferensi pada tataran leksikal. Unsur leksikal yang ditemukan adalah udah, ngegosip, aja, kaya, maen,ngomongin, bikin onar, gue,cuma, ngomong, sana, gak usah, gabung, sorry, kalo, nggabung, sama, lo, gak level, jelasin, sampesampe,udahbilang, matahin, males, maafin. Unsur leksikal tersebut ada padanannya dalam bahasa Indonesia. Kata udahberpadan dengan sudah, kata ngegosip berpadan dengan bergosip, kata aja berpadan dengan kata saja, kata kaya berpadan dengan seperti, kata maen berpadan dengan main, kata ngomongin berpadan dengan membicarakan, kata bikin onar berpadan dengan membuat kerusuhan, kata gue berpadan dengan aku/saya, kata cuma berpadan dengan hanya, kata ngomong berpadan dengan bicara, kata sana berpadan dengan kata ke sana, kata gak usah berpadan dengan kata tidak usah, kata gabung berpadan dengan kata bergabung, kata sorry berpadan dengan kata maaf, kata kalo berpadan dengan kata kalau, kata nggabung berpadan dengan kata bergabung, kata sama berpadan dengan kata dengan, kata lo berpadan dengan kata kamu, kata gak level berpadan dengan kata tidak sederajat, kata jelasin berpadan dengan kata menjelaskan, kata sampe-sampe berpadan dengan kata sampai-sampai, kata udahbilang berpadan dengan kata sudah katakan, kata matahin berpadan dengan kata mematahkan, kata males berpadan dengan kata malas, dan kata maafin berpadan dengan kata memaafkan.

Penggunaan unsur leksikal tersebut tampaknya dilatarbelakangi oleh beberapa alasan. Pertama, unsur leksikal tersebut digunakan sebagai sinonim kata yang sudah ada dalam bahasa Indonesia. Kedua, bentuk sebagian unsur leksikal bahasa gaul itu lebih singkat daripada padanannya dalam bahasa Indonesia. Selain itu, kemungkinan alasan lainnya 
adalah kesengajaan penulis untuk menghindari kekakuan dialog tokohnya.

3.25 Kisah Tiga Sekawan, Karya M. Hilmi Hidayat

Dalam cerpen yang berjudulKisah Tiga

Sekawan karya M. Hilmi Hidayat terdapat dua kalimat yang mengalami gejala interferensi pada tataran leksikal. Unsur leksikal yang ditemukan adalah $t u$ dan duluan. Unsur leksikal tersebut ada padanannya dalam bahasa Indonesia. Kata $t u$ berpadan dengan itu dan duluan berpadan dengan lebih dahulu.

Penggunaan unsur leksikal tersebut tampaknya dilatarbelakangi oleh beberapa alasan. Pertama, unsur leksikal tersebut digunakan sebagai sinonim kata yang sudah ada dalam bahasa Indonesia. Kedua, bentuk sebagian unsur leksikal bahasa itu lebih singkat daripada padanannya dalam bahasa Indonesia. Selain itu, kemungkinan alasan lainnya adalah kesengajaan penulis untuk menghindari kekakuan dialog tokohnya.

\subsection{Ujian Sekolah, Karya Nova Marjuita}

Pada cerpen yang berjudul Ujian Sekolah karya Nova Marjuita terdapat dua kalimat yang mengalami gejala interferensi pada tataran leksikal. Unsur leksikal yang ditemukan adalah bener, enggak, gimana, dankemaren.Unsur leksikal tersebut ada padanannya dalam bahasa Indonesia. Kata bener sepadan dengan benar, kata enggak sepadan dengan kata tidak, kata gimana sepadan dengan bagaimana, dankata kemaren sepadan dengan kemarin.

Penggunaan unsur leksikal tersebut tampaknya dilatarbelakangi oleh beberapa alasan. Pertama, unsur leksikal tersebut digunakan sebagai sinonim kata yang sudah ada dalam bahasa Indonesia. Kedua, kesengajaan penulis untuk menghindari kekakuan dialog tokohnya.

\subsection{Ujian Sekolah Datang, Karya Oki Winda Sari}

Dalam cerpen yang berjudulUjian

Sekolah Datang karya Oki Winda Sari terdapat beberapa kalimat yang mengalami gejala interferensi pada tataran leksikal. Unsur leksikal yang ditemukan adalah woy, lagi pada, lagi nyari, kirain, kemaren, dan udah. Unsur leksikal tersebut ada padanannya dalam bahasa Indonesia. Kata woy berpadan dengan hai, kata lagi pada berpadan dengan sedang, kata lagi nyari berpadan dengan sedang mencari, kata kirain berpadan dengan kupikir, kata kemaren berpadan dengan kemarin, dan kata $u d a h$ berpadan dengan kata sudah.

Penggunaan unsur leksikal tersebut tampaknya dilatarbelakangi oleh beberapa alasan. Pertama, unsur leksikal tersebut digunakan sebagai sinonim kata yang sudah ada dalam bahasa Indonesia. Kedua, bentuk sebagian unsur leksikal bahasa gaul itu adalah kesengajaan penulis untuk menghindari kekakuan dialog tokohnya.

\subsection{Kisah Persahabatan Tasya, Karya Qonita Puja Kesuma}

Pada cerpen Kisah persahabatan Tasya karya Qonita Puja Kesuma ditemukan beberapa interferensi leksikal. Interferensi yang ditemukan yaitu pada kata pesenin, samain ajalah, ayook, bareng, aja,gak, barengsama, oke, ngado, hallo, nangis gitu, astagfirullah, telpon, dan ambulance. Unsur-unsur leksikal tersebut ada padanannya dalam bahasa Indonesia. Kata pesenin sepadan dengan pesankan, kata samain sepadan dengan samakan, kata ajalah sepadan dengan sajalah, kata ayook sepadan dengan ayo, katabareng sepadan dengan kata bersama, kata aja sepadan dengan kata saja, kata gak sepadan dengan kata tidak, kata sama sepadan dengan kata dengan, kata oke sepadan dengan kata iya/baiklah, kata ngado sepadan dngan kata memberi 
kado, kata hallo sepadan dengan kata hai, kata nangis sepadan dengan kata menangis, kata gitu sepadan dengan kata begitu, kata telpon sepadan dengan kata telepon, kata ambulance sepadan dengan kata ambulans.

Penggunaan interferensi leksikal tersebut tampaknya dilatarbelakangi oleh beberapa alasan. Pertama, unsur leksikal tersebut digunakan sebagai sinonim kata yang sudah ada dalam bahasa Indonesia. Kedua, bentuk sebagian unsur leksikal bahasa itu lebih singkat daripada padanannya dalam bahasa Indonesia. Selain itu, kemungkinan alasan lainnya adalah kesengajaan penulis untuk menghindari kekakuan dialog tokohnya.

\subsection{Ku Ingin Dulu Bukan Sekarang, Karya Rachmawati}

Dalam cerpen $K u$ Ingin Dulu Bukan Sekarang karya Rachmawati ditemukan beberapa kalimat yang mengandung interferensi leksikal. Interferensi yang ditemukan yaitu pada kata fikiran, berantem, dengernya, udah, enggak, capek, kaya gini, brantem, kayanya, beda deh, gitu gak, ungkapin aja, ceritain ajasama, liat, lebay lu, laper, udah deh, gimana. Unsur-unsur leksikal tersebut ada padanannya dalam bahasa Indonesia. Kata fikiran sepadan dengan kata pikiran, kataberantem sepadan dengan kata bertengkar, kata dengernya sepadan dengan kata mendengarnya, kata udah sepadan dengan kata sudah, kata enggak, kata capek sepadan dengan kata lelah, kata kaya gini sepadan dengan kata seperti ini, kata kayanya sepadan dengan kata sepertinya, kata beda sepadan dengan kata berbeda, kata gitu gak sepadan dengan kata begitu tidak, kata ungkapin aja sepadan dengan kata ungkapkan saja, kata ceritain sepadan dengan kata ceritakan, kata liat sepadan dengan kata lihat, kata lebay lu sepadan dengan kata berlebihan kamu, kata laper sepadan dengan kata lapar, kata udah deh sepadan dengan kata sudah deh, dan kata gimana sepadan dengan kata bagaimana.

Penggunaan interferensi leksikal tersebut tampaknya dilatarbelakangi oleh beberapa alasan. Pertama, unsur leksikal tersebut digunakan sebagai sinonim kata yang sudah ada dalam bahasa Indonesia. Kedua, bentuk sebagian unsur leksikal bahasa itu lebih singkat daripada padanannya dalam bahasa Indonesia. Selain itu, kemungkinan alasan lainnya adalah kesengajaan penulis untuk menghindari kekakuan dialog tokohnya.

\subsection{Anak Juragan Duren, Karya Ria Arum Utami}

Pada cerpen yang berjudul Anak Juragan Duren karya Ria Arum Utami ditemukan beberapa interferensi leksikal. Interferensi yang ditemukan yakni tau gak, gue, nganterin, gue ketawa, elo, mut. Kata tersebut bukan merupakan leksikal bahasa Indonesia. Kata-kata tersebut berasal dari bahasa gaul. Kata-kata tersebut sebenarnya ada padanannya dalam bahasa Indonesia. Kata tau gak sepadan dengan kata tahu tidak, kata gue sepadan dengan kata saya atau aku, kata nganterin sepadan dengan kata mengantarkan, kata ketawa sepadan dengan kata tertawa, kata elo sepadan dengan kata kamu, kata mut sesungguhnya berasal dari bahasa Inggris mood yang sepadan dengan kata semangat.

Pengunaan unsur leksikal tersebut tampaknya dilatarbelakangi oleh beberapa alasan. Pertama, unsur leksikal tersebut digunakan sebagai sinonim kata yang sudah ada dalam bahasa Indonesia. Kedua, bentuk sebagian unsur leksikal bahasa Jawa itu lebih singkat daripada padanannya dalam bahasa Indonesia. Selain itu, kemungkinan alasan lainnya adalah kesengajaan penulis untuk menghindari kekakuan dialog tokohnya. 


\subsection{Kancil yang Cerdas, Karya Rizki Hidayatullah}

Dalam cerpen yang berjudul Kancil yang Cerdas karya Rizki Hidayatullah terdapat beberapa kalimat yang mengalami gejala interferensi pada tataran leksikal. Dari data yang terkumpul ditemukan interferensi leksikal pada kata-kata kasian deh, bohongin, gak,sabaran, dikit, mangkanya. Kata-kata tersebut sesungguhnya ada padanan katanya dalam bahasa Indonesia. Kata kasian sepadan dengan kata kasihan, kata bohongin sepadan dengan kata bohongi, kata gak sepadan dengan kata tidak, kata sabaran sepadan dengan kata bersabar, kata dikit sepadan dengan kata sedikit, kata mangkanya sepadan dengan kata makanya.Interferensi leksikal ini bukanlah kata-kata dalam bahasa Indonesia melainkan bahasa gaul.

Interferensi leksikal pada cerpen ini sepertinya muncul karena beberapa alasan berikut. Pertama, unsur leksikal tersebut digunakan sebagai sinonim kata yang sudah ada dalam bahasa Indonesia. Kedua, kesengajaan penulis untuk memberi suasana yang berbeda yang menambah kesan akrab dalam dialog tokohnya.

\subsection{Contekan yang Berujung Kesialan, Karya Romi Anwar}

Pada cerpen yang berjudul Contekan yang Berujung Kesialan karya Romi Anwar ditemukan beberapa interferensi leksikal. Unsur-unsur leksikal yang ditemukan ada padanannya dalam bahasa Indonesia. Kata gue sepadan dengan kata aku/saya, kata apaan sepadan dengan kata apa, kata ngegosipin seoadan dengan kata bergosip, kata aja sepadan dengan kata saja, kata denger sepadan dengan kata dengar, kata slalu sepadan dengan kata selalu, kata gua sepadan dengan kata aku atau saya, kata cepetan sepadan dengan kata cepat, frasa pada mau nggak sepadan dengan frasa mau tidak, frasa kayak gitu sepadan dengan kata seperti itu, kata pake sepadan dengan kata pakai, kata nawarin sepadan dengan kata menawari, kata kalok sepadan dengan kata kalau, kata dapet sepadan dengan kata dapat, kata kayaknya sepadan dengan kata sepertinya, kata ngomong sepadan dengan kata bicara, kata sepinter sepadan dengan kata sepintar, kata udah sepadan dengan kata sudah, kata nanyain sepadan dengan kata bertanya, kataemangnya sepadan dengan kata memangnya, kata pantesan sepadan dengan kata pantas saja, kata nyontek sepadan dengan kata mencontek.

Penggunaan interferensi leksikal tersebut tampaknya dilatarbelakangi oleh beberapa alasan. Pertama, sebagai sinonim kata yang sudah ada dalam bahasa Indonesia. Kedua, kesengajaan penulis yang ingin dialog tokohnya bergulir seperti biasa dalam komunikasi secara lisan.

\subsection{Persahabatan Semut dan} Burung,KaryaSalbiyah Agustina

Dalam cerpen yang berjudul Persahabatan Semut dan Burung karya Salbiyah Agustina terdapat satu kalimat yang mengalami gejala interferensi pada tataran leksikal.

"Aduh aku sangat capek sekali seharian terbang, lebih baik aku tidur dulu di atas pohon yang sejuk ini."

Interferensi tersebut yaitu pada kata capek. Unsur leksikal tersebut ada padanannya dalam bahasa Indonesia. Kata capek berpadan dengan lelah.

\subsection{Pangeran Katak, Karya Sukeni}

Pada cerpen berjudul Pangeran Katak karya Sukeni ditemukan dua interferensi leksikal,interferensi tersebut terdapat dalam konteks kalimat berikut.

1. Sudah dulu ya, nanti aku dicariin sama ayahku. 
2. Katak kamu dari mana saja, dari tadi gak keliatan?

Kata-kata yang berupa interferensi dalam kalimat di atas adalah dicariin, dan gak keliatan. Kata-kata tersebut ada padanan katanya dalam bahasa Indonesia. Kata dicariin sepadan dengan kata dicari, kata sama sepadan dengan kata oleh, kata gak sepadan dengan kata tidak, kata keliatan sepadan dengan kata kelihatan.

Penggunaan unsur interferensi leksikal pada kalimat di atas, sepertinya muncul karena beberapa alasan berikut. Pertama, unsur leksikal tersebut digunakan sebagai sinonim kata yang sudah ada dalam bahasa Indonesia. Kedua, kesengajaan penulis untuk memberi suasana yang berbeda yang menambah kesan akrab dalam dialog tokohnya.

\subsection{Perpisahan Bukan Akhir Persahabatan Kita, Karya Tri Rastutiani}

Dalam cerpen yang berjudul Perpisahan Bukan Akhir Persahabatan Kita karya Tri Rastutiani terdapat beberapa kalimat yang mengalami gejala interferensi pada tataran leksikal. Interferensi leksikal dalam cerpen ini adalah dance, enggak, ketemuan,kalo, oke, trusss, diem, dengerin, lanjutin, gitu, tu, udahlah, mending, yok, udah, laper, ayok, lanjutin, keburu. Kata-kata tersebut berasal dari bahasa gaul. Kata-kata tersebut sebenarnya ada padanannya dalam bahasa Indonesia. Kata dance sepadan dengan kata menari, kata enggak sepadan dengan kata tidak, kata ketemuan sepadan dengan kata bertemu, kata kalo sepadan dengan kata kalau, kata oke sepadan dengan kata baiklah, kata trusss sepadan dengan kata terus, kata diem sepadan dengan kata diam, kata dengerin sepadan dengan kata dengarkan, kata lanjutin sepadan dengan kata lanjutkan, kata gitu sepadan dengan kata begitu, kata tu sepadan dengan kata itu, kata udahlah sepadan dengan kata sudahlah, kata mending sepadan dengan kata lebih baik, kata yok sepadan dengan kata ayo, kata udah sepadan dngan kata sudah, kata laper sepadan dengan kata lapar, kata ayok sepadan dengan kata kata ayo, kata lanjutin sepadan dengan kata lanjutkan, kata keburu sepadan dengan kata.

Interferensi leksikal yang ditemukan sepertinya muncul karena beberapa alasan berikut. Pertama, unsur leksikal tersebut digunakan sebagai sinonim kata yang sudah ada dalam bahasa Indonesia. Kedua, kesengajaan penulis untuk memberi suasana yang berbeda yang menambah kesan akrab dalam dialog tokohnya.

\subsection{Sekolah Baru, Karya Tri Yana Apriyanti}

Pada cerpen yang berjudul Sekolah Baru karya Tri Yana Apriyanti terdapat beberapa kalimat yang mengalami gejala interferensi pada tataran leksikal. Dalam cerpen ini ditemukan kata emangnya, nanya, dan bareng. Kata-kata tersebut sebenarnya ada padanannya dalam bahasa Indonesia. Kata emangnya sepadan dengan kata sebenarnya, kata nanya sepadan dengan bertanya, dankata bareng sepadan dengan kata bersamasama.

Penggunaan unsur leksikal tersebut dilatarbelakangi oleh beberapa alasan. Pertama, unsur leksikal tersebut digunakan sebagai sinonim kata yang sudah ada dalam bahasa Indonesia. Kedua, bentuk sebagian unsur leksikal bahasa gaul itu lebih familiar daripada padanannya dalam bahasa Indonesia. Selain itu, kemungkinan alasan lainnya adalah kesengajaan penulis untuk menghindari kekakuan dialog tokohnya.

\subsection{Apa Salahku, Karya Veronika Cindy D.P.}

Dalam cerpen yang berjudul Apa Salahku karya Veronika Cindy D.P. terdapat 
beberapa kalimat yang mengalami gejala interferensi pada tataran leksikal. Katakata yang mengalami interferensi dalam cerpen ini adalah karna, capek, tauk, ngapain, nganterin, males, make muka melas, yes, trus, kayak mana, aja, udah,menggoglek-goglek.Kata karna sepadan dengan kata karena, kata capek sepadan dengan kata lelah, kata tauk sepadan dengan kata tahu, kata ngapain sepadan dengan kata sedang apa, kata nganterin sepadan dengan kata mengantarkan, kata males sepadan dengan kata malas, frasa make muka melas sepadan dengan frasa pasang muka memelas, kata yes sepadan dengan kata $y a$, kata trus sepadan dengan kata terus, kata kayak mana sepadan dengan kata bagaimana, kata aja sepadan dengan kata saja, kata udah sepadan dengan kata sudah, dan kata menggoglek-goglek sepadan dengan kata mengutak-atik.

Penggunaan unsur leksikal tersebut dilatarbelakangi oleh beberapa alasan. Pertama, unsur leksikal tersebut digunakan sebagai sinonim kata yang sudah ada dalam bahasa Indonesia. Kedua, bentuk sebagian unsur leksikal bahasa gaul itu lebih familiar daripada padanannya dalam bahasa Indonesia. Selain itu, kemungkinan alasan lainnya adalah kesengajaan penulis untuk menghindari kekakuan dialog tokohnya.

\subsection{Sahabat Terindah, Karya Windi Antika}

Dalam cerpen yang berjudul Sahabat Terindah karya Windi Antika terdapat beberapa kalimat yang mengalami gejala interferensi pada tataran leksikal. Katakata yang mengalami interferensi dalam cerpen ini adalah kringetan, enggak papa, ples, dimarahin, nambah. Kata kringetan sepadan dengan kata berkeringat, kata enggak papa sepadan dengan kata tidak apa-apa, kata ples sepadan dengan kata tambah, kata dimarahin sepadan dengan kata dimarahi, dan kata nambah sepadan dengan kata bertambah.

Penggunaan unsur leksikal tersebut dilatarbelakangi oleh beberapa alasan. Pertama, unsur leksikal tersebut digunakan sebagai sinonim kata yang sudah ada dalam bahasa Indonesia. Kedua, bentuk sebagian unsur leksikal bahasa gaul itu lebih familiar daripada padanannya dalam bahasa Indonesia. Selain itu, kemungkinan alasan lainnya adalah kesengajaan penulis untuk menghindari kekakuan dialog tokohnya.

\subsection{Kenangan, Karya Wulan Sri Adi Ningsih}

Dalam cerpen yang berjudul Kenangan karya Wulan Sri Adi Ningsih terdapat beberapa kalimat yang mengalami gejala interferensi pada tataran leksikal. Katakata yang muncul adalah $t u$, liat-liat dong, syapa, denger-denger, gak bisa akur, gimana,satuin, udah,ngejahilin, gak,aja, guys, bakal, secepet,bakalan, inget, dan sama. Kata tu sepadan dengan kata itu, kata liat-liat sepadan dengan kata lihat-lihat, kata syapa sepadan dengan kata siapa, kata denger-denger sepadan dengan kata dengar-dengar, frasa gak bisa akur sepadan dengan kata tidak bisa damai, kata gimana sepadan dengan kata bagaimana, kata satuin sepadan dengan kata satukan, kata udah sepadan dengan kata sudah, kata ngejahilin sepadan dngan kata menjahili, kata gak sepadan dengan kata tidak, kata aja sepadan dengan kata saja, kata guys sepadan dengan kata teman-teman, kata bakal sepadan dengan kata akan, kata secepet sepadan dengan kata secepat, kata bakalan sepadan dengan kata akan, kata inget sepadan dengan kata ingat, dankata sama sepadan dengan kata pada.

Penggunaan unsur leksikal tersebut dilatarbelakangi oleh beberapa alasan. Pertama, unsur leksikal tersebut digunakan sebagai sinonim kata yang sudah ada dalam bahasa Indonesia. 
Kedua, bentuk sebagian unsur leksikal bahasa Inggris dan Jawa itu lebih familiar daripada padanannya dalam bahasa Indonesia. Selain itu, kemungkinan alasan lainnya adalah kesengajaan penulis untuk menghindari kekakuan dialog tokohnya.

\subsection{Berlibur, Karya Yopi Hidayatullah}

Dalam cerpen yang berjudul Berlibur karya Yopi Hidayatullah terdapat beberapa kalimat yang mengalami gejala interferensi pada tataran leksikal.Katakata yang ditemukan adalah udah, sampek,deket, cepetan, enggak usah, capek-capek dorong, lagi, nambal, bentar,banget, boker coy, udahlah, dan gua. Kata udah sepadan dengan kata sudah, kata sampek sepadan dengan kata sampai, kata deket sepadan dengan kata dekat, kata cepetan sepadan dengan kata lebih cepat, kata enggak usah sepadan dengan kata tidak usah, frasa capekcapek dorong sepadan dengan kata lelahlelah mendorong, kata lagi sepadan dengan kata sedang, kata nambal sepadan dengan kata menambal, kata bentar sepadan dengan kata sebentar, kata banget sepadan dengan kata sekali, kata boker coy sepadan dengan buang air besar, kata udahlah sepadan dengan kata sudahlah, dan kata gua sepadan dengan kata aku/saya.

Penggunaan unsur leksikal tersebut dilatarbelakangi oleh beberapa alasan. Pertama, unsur leksikal tersebut digunakan sebagai sinonim kata yang sudah ada dalam bahasa Indonesia. Kedua, bentuk sebagian unsur leksikal bahasa gaul itu lebih familiar daripada padanannya dalam bahasa Indonesia. Selain itu, kemungkinan alasan lainnya adalah kesengajaan penulis untuk menghindari kekakuan dialog tokohnya.

\section{Simpulan}

Pemakaian bahasa Indonesia dalam cerpen-cerpen yang ditulis oleh siswa dan siswi SMP Negeri 2 Merbau Mataram, Kabupaten Lampung Selatan, Provinsi Lampung ternyata diwarnai oleh interferensi dari bahasa asing (Inggris), bahasa gaul, dan bahasa daerah. Interferensi tersebut terjadi pada tataran morfologi, tataran leksikal, dan tataran sintaksis.

Dari 40 cerpen yang diteliti ternyata ada 35 cerpen yang mengandung unsur interferensi. Hanya ada lima cerpen yang tidak diwarnai unsur interferensi. Apabila dipersentasekan secara keseluruhan ternyata cerpen siswa yang mengandung interferensi adalah $87,5 \%$ dan yang tidak mengandung interferensi ada $12,5 \%$.

Dari 35 cerpen yang mengandung interferensi, ditemukan 259 kalimat yang mengandung kosakata bahasa asing, bahasa daerah, dan bahasa gaul. Apabila dirata-ratakan maka tiap cerpen mengandung 6,5 kata bahasa asing, bahasa daerah, dan bahasa gaul.

Pada tataran leksikal, interferensi terjadi pada kata atau bentuk dasar yang meliputi kata benda, kata sifat, dan kata kerja, kata atau bentuk berimbuhan, kata atau bentuk ulang, dan bentuk kelompok kata yang meliputi frasa dan klausa. Interferensi pada tataran leksikal ini berjumlah sangat banyak, terutama pada bentuk kata dasar.

Berdasarkan data yang diperoleh, penulis menyimpulkan bahwa interferensi yang terjadi kemungkinan disebabkan oleh beberapa faktor. Faktor pertama adalah kedwibahasaan siswa. Sebagai dwibahasawan, siswa lebih menyukai bahasa gaul untuk menuangkan idenya. Selain itu kebiasaan sehari-hari siswa menggunakan bahasa gaul, bahasa daerah, dan bahasa asing lainnya menyebabkan terjadinya kurang kontrol terhadap bahasa yang digunakan saat menulis cerpen. Faktor kedua adalah 
sinonim. Unsur leksikal bahasa asing dan bahasa daerah yang digunakan oleh penulis cerpen adalah sebagai variasi dalam pemilihan kata. Dengan demikian, pemakaian kata yang sama secara berulang-ulang yang dapat menimbulkan kebosanan atau kejenuhan dapat dihindari. Faktor ketiga adalah prestise bahasa asing, bahasa gaul, dan bahasa daerah. Penulis cerpen ingin menunjukkan bahwa ia menguasai bahasa yang dianggap berprestise tersebut. Faktor keempat adalah demi menghindari kekakuan dalam berkomunikasi antara penulis dan pembacanya. Kecenderungan ini walaupun menimbulkan sikap kurang positif terhadap bahasa Indonesia namun untuk sebuah karya sastra berfungsi sangat penting karena di situlah letak keunikan karya fiksi. Kelima adalah unsur bahasa Inggris, bahasa gaul, dan bahasa daerah yang digunakan lebih singkat atau lebih pendek daripada padanannya dalam bahasa Indonesia sehingga penulis cerpen cenderung untuk menggunakan bahasa-bahasa tersebut. Faktor keenam adalah unsur bahasa asing dan bahasa daerah tersebut belum ada padanannya dalam bahasa Indonesia.
Daftar Pustaka

Nurgiyantoro, Burhan. 2000. Teori

Pengkajian Fiksi. Jogjakarta:

Gadjah Mada University Press.

Nababan, P.W.J. 1993. Sosiolinguistik:

Suatu Pengantar. Jakarta:

Gramedia.

Chaer, Abdul dan Leonie agustina. 2010.

Sosiolinguistik: Perkenalan Awal.

Jakarta: Rineka Cipta

Sumardjo, Jakob dan Saini K.M.. 1997.

Apresiasi Kesusastraan. Jakarta:

Gramedia Pustaka Utama.

Kridalaksana, Harimurti. 1993. Kamus

Linguistik. Jakarta: Gramedia.

Rahardi, Kunjana. 2001. Sosiolinguistik,

Kode dan Alih Kode. Yogyakarta:

Pustaka Pelajar.

Rusyana, Yus. 1989. Perihal

Kedwibahasaan. Jakarta: P2LPTK.

Sumarsono. 2011. Sosiolinguistik.

Yogyakarta: Pustaka Pelajar

Soewito. 1983. Sosiolinguistik: Teori dan

Problema. Surakarta:Kenary Offset.

Tarigan, H.G. 1986. Prinsip-prinsip

Dasar Sastra. Bandung: Angkasa. 